\title{
Ano-rectal neuroendocrine tumor: from a polyp with a good prognosis to a lethal carcinoma
}

\author{
Tumor neuroendocrino ano-rectal: desde un pólipo con buen pronóstico hasta un \\ carcinoma letal
}

\author{
Beatriz De Andrés-Asenjo ${ }^{1 *}$, Francisco J. Ortiz de Solórzano-Aurusa ${ }^{1}$ Henar Borrego-Pintado², \\ Francisco Blanco-Antona ${ }^{1}$, Alejandro Romero-de Diego ${ }^{1}$ and Juan Beltrán de Heredia-Rentería ${ }^{1}$ \\ ${ }^{1}$ General Surgery and Digestive System Department; ${ }^{2}$ Pathological Anatomy Department. Hospital Clínico Universitario de Valladolid, Valladolid, \\ Spain
}

\begin{abstract}
Background: Although rectal neuroendocrine tumors are rare neoplasms, their incidence is increasing in the last three decades. The objective of this work is to study the behavior of these tumors based on their clinical, diagnostic, therapeutic, and pathological variables in a tertiary hospital. Method: Retrospective study of rectal neuroendocrine tumors from 2000 to 2017 in our hospital. A computerized search was performed in the SNOMED program of the pathological anatomy service, using the criteria "neuroendocrine tumor" and "carcinoid tumor". Results: We found 16 patients with ano-rectal neuroendocrine tumor; $75 \%$ were male. The median age was 53 years (range: 34-83). The diagnosis was incidental in 62.5\%, with endoscopic treatment in 13 patients (81\%) and surgical treatment in $3(19 \%) .75 \%$ of the lesions were $11.68 .7 \%$ of the tumors showed a degree of G1 aggression. The mean follow-up was 29 months; no recurrences. During follow-up, three patients died (18.5\%), all of them with metastatic G3 tumor and the mean survival was 8 months. Conclusions: The rectal neuroendocrine tumors are increasingly frequent and present variable patterns, whose prognosis will depend on their histological aggressiveness. The increase incidence may be due to a greater awareness of the existence of these tumors, to colorectal cancer screening, to the increase in the number of colonoscopies performed and to the generalization of histological studies with neuroendocrine markers.
\end{abstract}

Key words: Rectal carcinoid. Neuroendocrine tumor. Rectal neoplasm.

\section{Resumen}

Introducción: Aunque los tumores neuroendocrinos rectales son neoplasias poco frecuentes, su incidencia está aumentando en las tres últimas décadas. El objetivo de este trabajo es el estudio del comportamiento de dichos tumores basándonos en sus variables clínicas, diagnósticas, terapéuticas y anatomopatológicas en un hospital terciario. Método: Estudio retrospectivo de los tumores neuroendocrinos rectales desde el año 2000 hasta el año 2017 en nuestro hospital. Se realizó una búsqueda informatizada en el programa SNOMED del servicio de anatomía patológica, empleando los criterios «tumor neuroendocrino» y «tumor carcinoide». Resultados: Se hallaron 16 pacientes con tumor neuroendocrino ano-rectal. El 75\% eran varones. La mediana de edad fue de 53 años (rango: 34-83). El diagnóstico fue incidental en el 62,5\%. El tratamiento fue endoscópico en 13 (81\%) pacientes y quirúrgico en 3 (19\%). El 75\% de las lesiones fueron T1. El 68,7\% de los tumores presentaban un

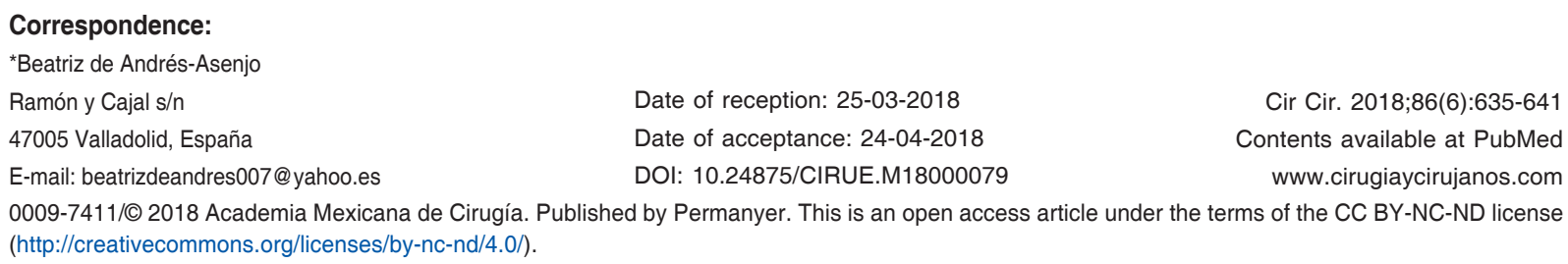

Cir Cir. 2018;86(6):635-641 Contents available at PubMed www.cirugiaycirujanos.com 0009-7411/@ 2018 Academia Mexicana de Cirugía. Published by Permanyer. This is an open access article under the terms of the CC BY-NC-ND license (http://creativecommons.org/licenses/by-nc-nd/4.0/). 
grado de agresividad G1. La media de seguimiento fue de 29 meses; no hubo recidivas. Durante el seguimiento fallecieron 3 (18,5\%) pacientes, todos ellos con tumor G3 metastásico, y la supervivencia media fue de 8 meses. Conclusiones: Los tumores neuroendocrinos rectales son cada vez más frecuentes y presentan unos patrones variables, cuyo pronóstico dependerá de su agresividad histológica. El aumento de su incidencia puede deberse a una mayor concienciación de la existencia de estos tumores, a las campañas de cribado del cáncer colorrectal, al aumento del número de colonoscopias realizadas y a la generalización de los estudios histológicos con marcadores neuroendocrinos.

Palabras clave: Carcinoide rectal. Tumor neuroendocrino. Neoplasia rectal.

\section{Introduction}

In 1888, Lubarsch described a type of tumors originating in neuroendocrine cells ${ }^{1}$, and in 1907, Obendorfer called these tumors "carcinoid" (carcinoma-like tumor)2; currently, using the term "neuroendocrine tumor" (NET) is recommended, owing to a greater precision when describing its etiology and location ${ }^{3-6}$.

Rectal NETs (RNET) account for $17.7 \%$ of total NETs and for $27 \%$ of gastro-entero-pancreatic tumors (GEPNET). Its approximate incidence is 0.86 per 100,000 population, with an $8.2 \%$ annual increase ${ }^{7,8}$. In the USA, NETs are more common, especially in black males, and there seems to be a higher predisposition in the Asian population, ${ }^{5,8-12}$. In the Spanish Registry of Neuroendocrine Tumors (RGETNE -Registro Español de Tumores Neuroendócrinos) GEPNET are ranked fourth $(6 \%)$, after small intestine, appendix and stomach tumors ${ }^{13}$.

RNETs are generally small and single tumors that are most commonly diagnosed in asymptomatic patients during a colonoscopy performed in an early cancer screening campaign or for the study of another colorectal pathology ${ }^{12}$. Sometimes they have local symptoms, such as rectal bleeding, pain or intestinal rhythm disturbances, with carcinoid syndrome being of infrequent occurrence. Their treatment varies from endoscopic polypectomy to trans-anal excision, and therefore both this and prognosis will depend on tumor size and rectal wall invasion, $5,12,14-16$.

The purpose of this work is to perform a review of RNETs diagnosed in a tertiary care hospital during 16 years, based on their clinical, diagnostic, therapeutic, prognostic and anatomopathological aspects.

\section{Method}

A retrospective study of patients diagnosed with anorectal NET between January 2000 and January 2017 was carried out. The study was approved by the ethics committee of our hospital, and is part of the research project Study of gastrointestinal and pancreatic neuroendocrine tumors, approved by the University Clinical Hospital of Valladolid (Spain) Research Commission, and has been carried out after obtaining written informed consent from all patients after having been explained the procedure.

For the computed search, the criteria "tumor neuroendocrino" (neuroendocrine tumor) and "carcinoide" (carcinoid) were used in the SNOMED program of the anatomical pathology department.

The following variables were studied: age, gender, clinical manifestations, history of colorectal pathology, tumor location, chromogranin $\mathrm{A}(\mathrm{CgA})$ blood markers and 5-hydroxyindoleacetic (5-HIAA) urine markers, presence of metastases, type of treatment (endoscopic or surgical), postoperative complications, mortality, need for adjuvant treatment, followup time, TNM classification, stage and degree of tumor aggressiveness.

In addition to hematoxylin-eosin staining, immunohistochemical techniques were used for $\mathrm{CgA}$ and synaptophysin neuroendocrine markers, as well as for Ki-67 proliferation rate (Fig. 1).

For tumor classification and staging, the 2009 TNM system of the Union for International Cancer Control ${ }^{17}$ was used, and for aggressiveness gradation, the World Health Organization 2010 criteria for GEPNET were used ${ }^{18}$.

The database and its descriptive analysis were carried out with the IBM SPSS statistical package, version 20 .

\section{Results}

Sixteen RNETs were diagnosed in the 17 years that were reviewed, 12 in men (75\%) and 4 in women (25\%). Out of these tumors, $81.3 \%(n=13)$ were diagnosed in the last 4.5 years preceding the study (Fig. 2). Average age was 58 years, with a median of 53 (range: 34-83). 


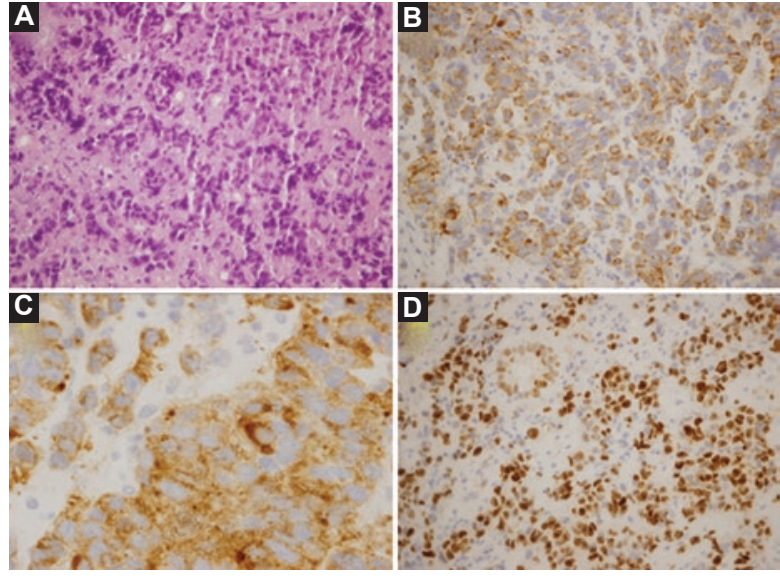

Figure 1. Rectal neuroendocrine tumors histological study. A: hematoxylin-eosin, 40x. B: positive chromogranin, 40x. C: positive synaptophysin, 40x. D: > 20\% Ki-67.

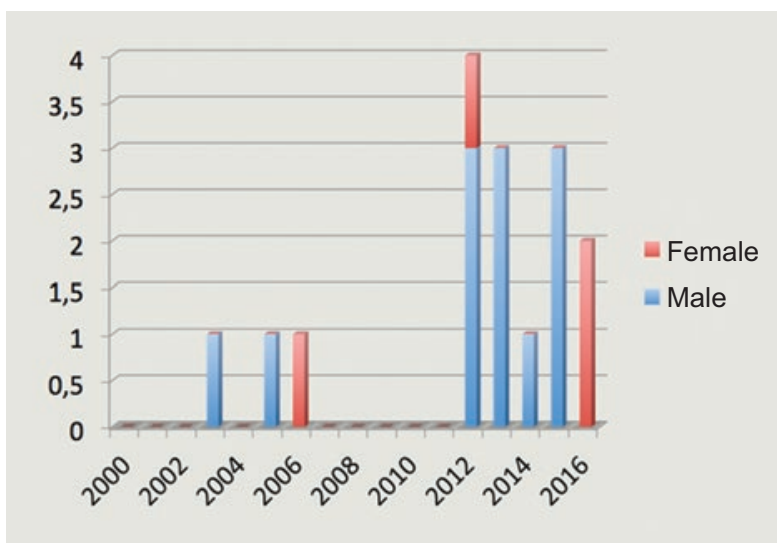

Figure 2. Incidence of 16 rectal neuroendocrine tumors by year and gender.

Ten RNETs (62.5\%) were detected in asymptomatic patients, seven in colonoscopies performed during the colorectal cancer screening campaign and the other three during the control of a ulcerative colitis, in the study of a high digestive hemorrhage and during the diagnosis of a condition of chronic constipation. Among the symptomatic patients, five had rectorrhagia and another a painful tumor in the anal canal. At diagnosis, no patient had a typical carcinoid syndrome with skin flush and diarrhea, although this syndrome was observed during follow-up of two tumors with distant spread.

In 5 patients $(31 \%)$, there was a history of colorectal pathology: three polyps, an ulcerative colitis and a rectum neoplasm treated with endoanal resection.

The RNET diagnosis was established after colonoscopy and tumor biopsy. All were single lesions and

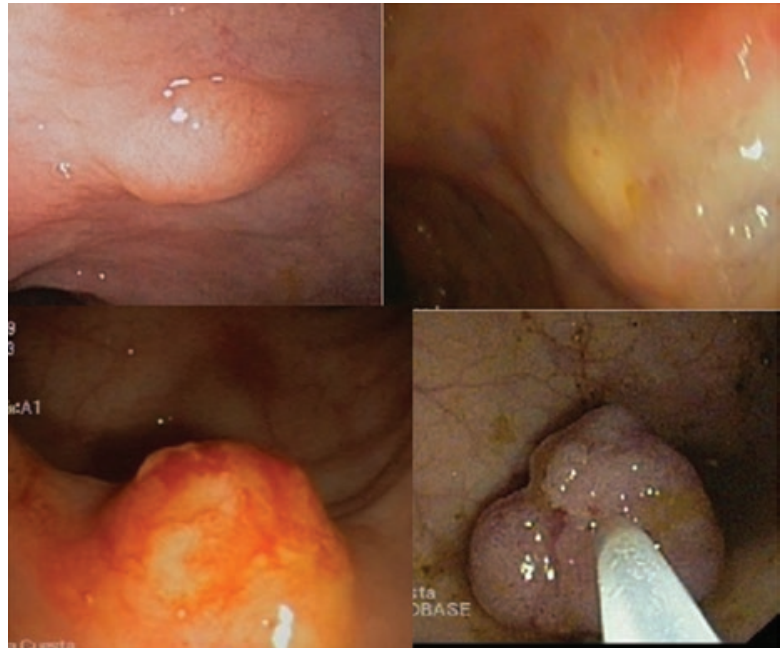

Figure 3. Endoscopic aspects of rectal neuroendocrine tumors.

the most common location were the lower two thirds of the rectum (14 cases, $87.5 \%$ ), except for one tumor that was in the upper rectal third and another in the anal canal (Fig. 3).

Serum $\mathrm{CgA}$ concentrations were analyzed in 9 cases $(56 \%)$, and were found to be high in $3(33 \%)$. Urinary 5 -HIAA in was assessed in 10 cases $(62.5 \%)$, and it was normal in $100 \%$.

Complementary studies for diagnosis and follow-up included:

- Computed tomography (CT) in 14 patients $(87.5 \%)$, which was pathological in $5(35.7 \%)$ with liver and bone metastases and regional lymph node dissemination being detected. As an incidental finding, one patient was diagnosed with appendiceal mucocele.

- Scintigraphy with somatostatin analogs (SSA) in 10 patients $(62.5 \%)$; in nine of them it was associated with single-photon emission CT (SPECT). At diagnosis, it was normal in $100 \%$ of cases, and during follow-up of a G3 tumor a liver metastasis was detected.

- Endoscopic ultrasound (EUS) in 8 patients (50\%), which in two was performed prior to tumor resection and showed the existence of a tumor without muscularis propria invasion or lymph node involvement (Fig. 4). In the remaining six patients, it was used during follow-up, without any lesion being found.

- Five magnetic resonance imaging (MRI) studies were performed, with two lymph node disseminations and one case of bone metastasis being diagnosed. 


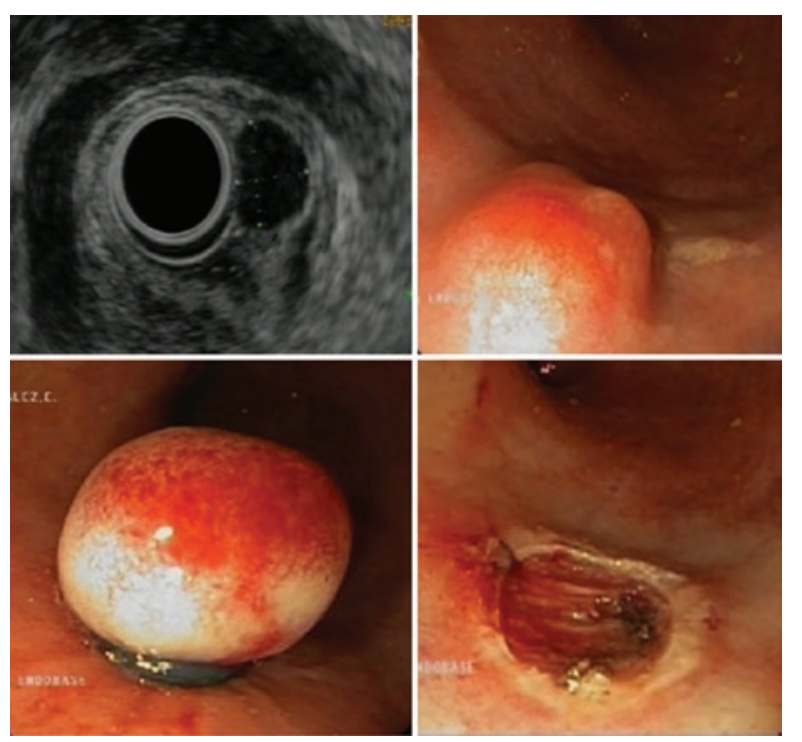

Figure 4. Rectal neuroendocrine tumor: echoendoscopy (top left image) and polypectomy with elastic band.

- In an undifferentiated anal canal tumor, negative on scintigraphy with SSAs, a positron emission (PET) CT scan was performed where regional lymph node dissemination was detected.

Endoscopic treatment was carried out in 13 patients (81\%): 10 simple resections and one with elastic band ligation (Fig. 4); a stenosing tumor with metastatic dissemination was treated with a colonic stent, and a biopsy was performed in a metastatic tumor.

Three patients (18.7\%) were surgically intervened. The techniques used were anal tumor excision of and inguinal lymph node biopsy, an endoanal resection and an abdominoperineal amputation. There was no perioperative mortality. The abdominoperineal amputation developed an infection of the perineal wound. In the case of the RNET-associated appendiceal mucocele, a programmed laparoscopic appendectomy was practiced.

The TNM classification, the stage and the degree of aggressiveness at diagnosis are shown in table 1. Twelve lesions $(75 \%)$ were $\mathrm{T} 1$ and $69 \%(\mathrm{n}=11)$ were at stage I and G1. Every patient with a G3 tumor $(n=5)$ had regional lymph node involvement, and three of them had distant metastasis.

The anatomopathological report did not specify the status of the resection borders in 7 cases (43.7\%), in $3(18.7 \%)$, they were disease-free and in $6(37.5 \%)$, they were compromised. Two G3 tumors had vascular invasion and one of them had an associated adenocarcinoma component.
Table 1. TNM classification, stage and grade at diagnosis in the 16 rectal neuroendocrine tumors

\begin{tabular}{|c|c|c|c|c|c|c|c|c|c|}
\hline$T$ & n (\%) & $\mathrm{N}$ & n (\%) & $M$ & $\mathrm{~N}(\%)$ & Stage & n (\%) & Grade & n (\%) \\
\hline T1a & $10(62)$ & $N x$ & - & MO & - & I & $11(69)$ & G1 & $11(69)$ \\
\hline $\mathrm{T} 1 \mathrm{~b}$ & $2(12)$ & NO & - & M1 & $3(19)$ & Ila & - & G2 & - \\
\hline T2 & $1(6)$ & N1 & $5(31)$ & & & IIb & - & G3 & $5(31)$ \\
\hline T3 & $1(6)$ & & & & & IIIa & - & & \\
\hline \multirow[t]{2}{*}{$\mathrm{T} 4$} & $2(12)$ & & & & & IIIb & $2(12)$ & & \\
\hline & & & & & & IV & $3(19)$ & & \\
\hline
\end{tabular}

In 11 patients (68.7\%) there were other colonic synchronous lesions: 10 polyps (eight adenomatous and two hyperplastic), one ulcerative colitis, one nonspecific chronic colitis and carcinoma in situ plus appendiceal mucocele.

After surgical treatment, four patients with a G3 RNET received adjuvant treatment, three with chemotherapy (associating radiotherapy in two of them) and one (with carcinoid syndrome) with somatostatin analogs (SSAs).

Mean follow-up was 26 months, with a median of 12 (range: 0.5-109). None of the studied patients had local recurrence. A grade G1 RNET with positive margins after endoscopic resection had high $\mathrm{CgA}$ values, for which controls were carried out with SPECT, endoscopy and EUS, which were normal, and was discharged after 5 years of periodic reviews. During the follow-up, 3 patients (18.7\%) died, all of them with grade G3 metastatic RNET, and mean survival was 8.3 months.

\section{Discussion}

RNETs have gone from being considered an infrequent type of rectal neoplasm to be an increasingly common finding in clinical practice ${ }^{19}$. The wide dissemination of endoscopic tests, the campaigns for colorectal carcinoma screening, generalization of histological studies using neuroendocrine markers and better data collection in hospital records are the factors that would explain this increased incidence $e^{7,9,10,20,21}$. In our work, $81 \%$ of cases were diagnosed in the last years of the study, which is also attributed to the previously exposed factors.

NETs anal location is quite rare and, as in the only case of our series, they are usually aggressive neoplasms $^{22}$. In the review carried out by the USA 
National Cancer Institute, Surveillance Epidemiology and End Results, covering from 1950 to 2007, out of 31,644 GEPNETs recorded only $0.2 \%$ were located in the anal region ${ }^{7}$, while in the RGETNE, no tumor is found located in the anus ${ }^{13}$.

At diagnosis, most rectal carcinoid tumors (75-96\%) are localized, which is consistent with our series (69\%). The existence of metastasis varies according to the size and degree of aggressiveness of the tumors ${ }^{10,12,15,23}$; in our review, we have observed that all tumors with disseminated disease at diagnosis were G3.

Mean age of patients with RNET in most series, as well as in ours, is between the fifth and sixth decades of the life $7,8,19,21,24-27$. The male gender is the most affected by RNETs ${ }^{8}$, which is quite evident in our series, with $75 \%$ of males, although this difference is not so marked in other works ${ }^{13,21,27,28}$ and in some studies these malignancies even predominate in women ${ }^{24,26}$.

Clinical aspects were similar to those published in the literature, since most RNETs usually occur in asymptomatic patients. When there are clinical symptoms, local symptoms are usually predominant, including rectorrhoea, anorectal pain, unexplained weight loss or altered bowel movements. The presence of a typical carcinoid syndrome is rare and usually occurs in cases with metastatic disease ${ }^{23}$, as it occurred in both cases (12.5\%) of our series.

The main diagnostic test in RNETs is low endoscopy, since most of these tumors are located at between 5 and $10 \mathrm{~cm}$ from the anal margin ${ }^{3.27}$. Its typical appearance is a submucosal lesion, rounded, soft in consistency, covered with a mucosa of normal or yellowish color. The presence of ulceration, central depression or hyperemia is atypical and is associated with parietal and lymphatic invasion ${ }^{29,30}$.

Colonoscopy must be complete in order to enable ruling out other synchronous lesions, such as adenocarcinoma, whose association is common ${ }^{6,12,23}(12.5 \%$ in our review).

Another diagnostic test is 5-HIAA determination, although it is not very useful since very few RNETs produce serotonin. $\mathrm{CgA}$ serum concentrations are usually normal, except when there is metastatic disease, and its determination is recommended as a tumor marker in the follow-up of patients with poor progno$\mathrm{sis}^{19}$. Other determinations that can be altered in these tumors are carcinoembryonic antigen, prostate-specific antigen, beta chorionic gonadotropin hormone, pancreatic polypeptide and glucagon-like peptide ${ }^{3,23}$.

EUS and MRI are also highly useful diagnostic methods to determine invasion of the rectal wall and existence of regional adenopathies ${ }^{29}$. Their employment can be useful to determine if endoscopic treatment or surgical resection is going to be carried out in those endoscopically atypical cases, in $>1 \mathrm{~cm}$ lesions, or if in the histological examination there is margin invasion or data consistent with poor prognosis (muscularis propria infiltration, lymphovascular invasion, mitotic index $>2 / 10$ high power field (HMF) or Ki-67 > 2\%) $)^{3,10,19,31,32}$.

For the detection of distant metastases, the tests of choice are thoracoabdominal CT and liver MRI23.

Scintigraphy with SSA or SPECT are indicated in tumors $>2 \mathrm{~cm}$ for the assessment of metastatic dissemination; they are also useful for the selection and monitoring of treatments with SSAs or radionuclides. PET would be indicated in undifferentiated tumors, in which scintigraphy with SSA is usually negative ${ }^{3,23}$.

The only RNET curative treatment is its complete resection ${ }^{23}$. Therapeutic options vary according to its size, endoscopic appearance and risk factors ${ }^{10,24,25,29}$. Approximately $78 \%$ of RNETs are endoscopically treated, $10 \%$ with endoanal surgery and $12 \%$ with radical surgery ${ }^{21}$, which are similar figures to those we observed in our series.

In tumors $\leq 1 \mathrm{~cm}$ located in the mucosa/submucosa, simple polypectomy ${ }^{15,33}$ or endoscopic mucosal resection with suction head or with elastic band ligation $3,28,34$ can be performed. To obtain greater resection depth, some authors propose a submucosal endoscopic dissection $^{26,35}$. Advanced endoscopic resection techniques seem to achieve a higher rate of negative margins, without complications significantly increasing ${ }^{10,36,37}$, although certain authors do not find significant differences and consider that endoscopic technique should be chosen considering factors such as cost-effectiveness and experience at each center ${ }^{38}$.

The existence of compromised or undetermined margins after endoscopic resection ranges from 16 to $83 \%{ }^{33.39-41}$. In our series, $43.7 \%$ of undetermined margins and $37.5 \%$ of compromised margins were observed. In differentiated tumors, resection margin compromise appears not to be of prognostic importance, although it forces the performance of a control EUS and more strict patient monitoring, unlike cases of poor prognosis, where the existence of positive margins forces a new, more aggressive resection ${ }^{3,27,40}$.

Tumors $>2 \mathrm{~cm}$ that invade the muscularis propria layer or with histological criteria of aggressiveness should be treated with radical surgery, similar to adenocarcinoma ${ }^{3,5,14,19,30,42}$. In RNETs with distant dissemination, this surgery does not appear to provide 
an increased survival, but it can improve quality of life and prevent complications $\mathrm{s}^{3,23,32,43}$.

Treatment of intermediate cases $(1-2 \mathrm{~cm})$ is a more debated subject ${ }^{4}$, since if they are located in the mucosa-submucosa and have no risk factors, they can be treated with transanal microsurgery or with advanced endoscopic resection ${ }^{3,27}$, and if they are $>1.5$ $\mathrm{cm}$ or have risk factors radical surgery should be carried out ${ }^{10}$.

Adjuvant treatment with systemic chemotherapy is indicated in poorly-differentiated tumors ${ }^{44}$. SSAs can control the symptoms of carcinoid syndrome and, like interferon, their use as antitumor agents has limited evidence. Furthermore, in inoperable metastatic tumors with positive scintigraphy with SSA; radiotherapy

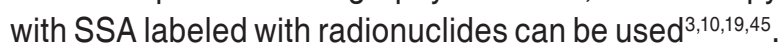
In our series, all patients with G3 RNET tumors received chemotherapy, and in two of them it was associated with radiotherapy.

There are few specific studies on the management of metastatic liver disease in RNET. Liver resection, encompassing from metastasectomy to liver transplantation, can be done with curative purpose, for symptom control or for tumor mass reduction. As alternative treatments or associated with liver resection, radiofrequency ablation and embolization or transarterial chemoembolization are used ${ }^{3}$.

Completely removed $<1 \mathrm{~cm}$ RNETs without risk factors do not require oncological monitoring, although performing a rectoscopy every 6 months for 2 years is advisable after endoscopic resection. In tumors with risk of local relapse or metastasis, performing periodic controls for 5 to 10 years with endoscopy, MRI, EUS, CT and $\operatorname{CgA}$ determinations is recommended ${ }^{19,23,46,47}$.

Five-year survival of patients with well- or moderately-differentiated RNETs varies depending on their stage: $92-100 \%$ for stage I, $80-88 \%$ for stage II; 51 $59 \%$ for stage III and $0-15 \%$ for stage IV $8,11,25,33,48,49$. Tumors with a high degree of aggressiveness have a poor prognosis, even those that are localized, with a mean survival of 13 months ${ }^{43}$. In our review, in patients with grade G3 RNET, we found a survival of less than 8.3 months.

\section{Conclusions}

RNETs are increasingly common in clinical practice, since their incidence is increasing due to a greater dissemination of endoscopic studies, to colorectal carcinoma screening campaigns, to a generalization of histological examination with specific neuroendocrine markers, to better data collection in hospital records and to an increased awareness on the existence of these tumors. Its prevalence is also increasing because patients are having a longer survival. We must keep in mind the need for a multidisciplinary team to be in charge of its management, especially in advanced cases, according to the guidelines agreed by various scientific societies $4,6,21,23,46,47,50,51$, in order to prevent the performance of expensive, ineffective diagnostic tests, to achieve standardization of its treatment and carry out an adequate follow-up for each patient.

\section{Funding}

This work has not been funded by any public or private organization.

\section{Conflict of interests}

The authors have no conflicts of interest.

\section{References}

1. Lubarsch O. Uber den primaren Krebs des lleum nebst Bemerkungen uber das gleichzeitige Vorkommen von Krebs und Tuberkulose. Virchows Arch. 1888;3:280-317.

2. Oberndorfer S. Karzinoid Tumore des Dunndarms. Frankf Z Pathol. 1907;1:426-30.

3. Mandair D, Caplin M. Colonic and rectal NET's. Best Pract Res Clin Gastroenterol. 2012;26:775-89.

4. Ramage J, Ahmed A, Ardill J, Bax N, Breen J, Caplin M, et al. Guidelines for the management of gastroentero-pancreatic neuroendocrine (including carcinoid) tumours (NETs). Gut. 2012;61:6-32.

5. Pasieka J. Carcinoids tumors. Surg Clin N Am. 2009;89:1123-37.

6. Kocha W, Maroun J, Kennecke H, Law C, Metrakos P, Ouellet J, et al. Consensus recommendations for the diagnosis and management of well-differentiated gastroenterohepatic neuroendocrine tumours: a revised statement from a Canadian National Expert Group. Curr Oncol. 2010;17:49-63.

7. Lawrence B, Gustafsson B, Chan A, Svejda B, Kidd M, Modlin I. The epidemiology of gastroenteropancreatic neuroendocrine tumors. Endocrinol Metab Clin N Am. 2011;40:1-18.

8. Yao JC, Hassan M, Phan A, Dagohoy C, Leary C, Mares J, et al. One hundred years after "carcinoid": epidemiology of and prognostic factors for neuroendocrine tumors in 35,825 cases in the United States. J Clin Oncol. 2008;26:3063-72.

9. Jetmore A, Ray J, Gathright J, McMullen K, Hicks T, Timmeke A. Rectal carcinoids: the most frequent carcinoid tumor. Dis Colon Rectum. 1992;35:717-25.

10. De Mestier L, Brixi H, Gincul R, Ponchon T, Cadiot G. Updating the management of patients with rectal neuroendocrine tumors. Endoscopy. 2013;45:1039-46.

11. Modlin I, Lye K, Kidd M. A 5-decade analysis of 13,715 carcinoid tumors. Cancer. 2003;97:934-59.

12. Modlin I, Kidd M, Latich I, Zikusoka M, Shapiro M. Current status of gastrointestinal carcinoids. Gastroenterology. 2005;128:1717-51.

13. García-Carbonero R, Capdevila J, Crespo-Herrero G, Díaz-Pérez J, Martínez del Prado, Alonso Orduña V, et al. Incidence, patterns of care and prognostic factors for outcome of gastroenteropancreatic neuroendocrine tumors (GEP-NETs): results from the National Cancer Registry of Spain (RGETNE). Ann Oncol. 2010;21:1794-803.

14. Partelli S, Maurizi A, Tamburrino D, Baldoni A, Polenta V, Crippa S, et al. A review on surgery of gastro-entero-pancreatic neuroendocrine tumors. Eur J Endocrinol. 2014;171:153-62.

15. Mani S, Modlin I, Ballantyne G, Ahlman H, West B. Carcinoids of the rectum. J Am Coll Surg. 1994;179:231-48. 
16. Jann H, Roll S, Couvelard A, Hentic O, Pavel M, Müller-Nordhorn J, et al. Neuroendocrine tumors of midgut and hindgut origin: tumor-node-metastasis classification determines clinical outcome. Cancer. 2011;117: 3332-41.

17. UICC (International Union Against Cancer). TNM Classification of malignant tumours. $7^{\text {th }}$ ed. Chichester, West Sussex, UK; Hoboken, NJ: Wiley-Blackwell; 2009.

18. Bosman F, Carneiro F, Hruban R, Theise N, editores. WHO Classification of tumours of the digestive system. Lyon, France: IARC; 2010.

19. Errasti J, Espín E, Reina A. Neoplasias de recto poco frecuentes. Revisión de conjunto. Cir Esp. 2014;92:579-88.

20. Fraenkel M, Kim M, Faggiano A, Herder W, Valk G. Incidence of gastro-enteropancreatic neuroendocrine tumours: a systematic review of the literature. Endocr Relat Cancer. 2014;21:153-63.

21. McDermott F, Heeney A, Courtney D, Mohan H, Winter D. Rectal carcinoids: a systematic review. Surg Endosc. 2014;28:2020-6.

22. Sebastián Ayala $R$, Concha Sierralta $M$, Domínguez Vera $A$, Canelo Ruiz P. Tumor carcinoide de ano, presentación de un caso y revisión de la literatura. Revista de la Facultad de Medicina Humana de la Universidad Ricardo Palma. 2013;1:42-5.

23. Caplin M, Sundin A, Nillson O, Baum P, Klose K, Kelestimur F, et al. ENETS consensus guidelines for the management of patients with digestive neuroendocrine neoplasms: colorectal neuroendocrine neoplasms. Neuroendocrinology. 2012;95:88-97.

24. Fahy B, Tang L, Klimstra D, Wong W, Guillem J, Paty P, et al. Carcinoid of the rectum risk stratification (CaRRs): a strategy for preoperative outcome assessment. Ann Surg Oncol. 2007;14:1735-43.

25. Shields C, Tiret E, Winter D, International Rectal Carcinoid Study Group. Carcinoid tumors of the rectum: a multi-institutional international collaboration. Ann Surg. 2010;252:750-5.

26. Ono A, Fujii T, Saito Y, Matsuda T, Lee DT, Gotoda T, et al. Endoscopic submucosal resection of rectal carcinoid tumors with a ligation device. Gastrointest Endosc. 2003;57:583-7.

27. Kumar A, Sidani S, Kolli K, Stahl T, Ayscue J, Fitzgerald J, et al. Transanal endoscopic microsurgery for rectal carcinoids: the largest reported United States experience. Colorectal Dis. 2012;14:562-6.

28. Ono A, Fujii T, Saito Y, Matsuda T, Lee D, Gotoda T, et al. Endoscopic submucosal resection of rectal carcinoid tumors with a ligation device. Gastrointest Endosc. 2003:57:583-7.

29. Zhou X, Xie H, Xie L, Li J, Fu W. Factors associated with lymph node metastasis in radically resected rectal carcinoids: a systematic review and meta-analysis. J Gastrointest Surg. 2013;17:1689-97.

30. Attili F, Capurso G, Vanella G, Fuccio L, Delle Fave G, Costamanga G, et al. Diagnostic and therapeutic role of endoscopy in gastroenteropancreatic neuroendocrine neoplasms. Dig Liver Dis. 2014;46:9-17.

31. Fujishima H, Misawa T, Maruoka A, Yoshinaga M, Chijiiwa $Y$, Nawata $H$. Rectal carcinoid tumor: endoscopic ultrasonographic detection and endoscopic removal. Eur J Radiol. 1993;16:198-200.

32. Koura A, Giacco G, Curley S, Skibber J, Feig B, Ellis L. Carcinoid tumors of the rectum: effect of size, histopathology, and surgical treatment on metastasis free survival. Cancer. 1997;79:1294-8.

33. Kim G, Kim K, Hong S, Yu E, Yang D, Jung K, et al. Clinical outcomes of rectal neuroendocrine tumors $\leq 10 \mathrm{~mm}$ following endoscopic resection. Endoscopy. 2013;45:1018-23.
34. Imada-Shirakata Y, Sakai M, Kajiyama T, Kin T, Inoue K, Torii A, et al. Endoscopic resection of rectal carcinoid tumors using aspiration lumpectomy. Endoscopy. 1997;29:34-8.

35. Fujishiro M, Yahagi N, Nakamura M, Kakushima N, Kodashima S, Ono S, et al. Successful outcomes of a novel endoscopic treatment for Gl tumors: endoscopic submucosal dissection with a mixture of high-molecular-weight hyaluronic acid, glycerin, and sugar. Gastrointest Endosc. 2006;63:243-9.

36. Zhong D, Shao L, Cai J. Endoscopic mucosal resection vs endoscopic submucosal dissection for rectal carcinoid tumours: a systematic review and meta-analysis. Colorectal Dis. 2012;15:283-91.

37. Zhou X, Xie H, Xie L, Li J, Cao W, Fu W. Endoscopic resection therapies for rectal neuroendocrine tumors: a systematic review and meta-analysis. J Gastroenterol Hepatol. 2014;29:259-68.

38. Onozato $\mathrm{Y}$, Kakizaki S, lizuka $\mathrm{H}$, Sohara N, Mori M, Itoh $\mathrm{H}$. Endoscopic treatment of rectal carcinoid tumors. Dis Colon Rectum. 2010;53:169-76.

39. Kobayashi K, Katsumata T, Yoshizawa S, Sada M, Igarashi M, Saigenji K, et al. Indications of endoscopic polypectomy for rectal carcinoid tumors and clinical usefulness of endoscopic ultrasonography. Dis Colon Rectum. 2005;48:285-91.

40. Kwaan M, Goldberg J, Bleday R. Rectal carcinoid tumors: review of results after endoscopic and surgical therapy. Arch Surg. 2008;143:471-5.

41. Park C, Cheon J, Kim J, Shin J, Jang B, Shin S, et al. Criteria for decision making after endoscopic resection of well-differentiated rectal carcinoids with regard to potential lymphatic spread. Endoscopy. 2011;43:790-5.

42. Larrad A. Síndrome carcinoide. Cir Esp. 1997;62:224-33.

43. Smith J, Reidy D, Goodman K, Shia J, Nash G. A retrospective review of 126 high-grade neuroendocrine carcinomas of the colon and rectum. Ann Surg Oncol. 2014;21:2956-62.

44. Sorbye H, Strosberg J, Baudin E, Klimstra D, Yao J. Gastroenteropancreatic high-grade neuroendocrine carcinoma. Cancer. 2014;120:2814-23.

45. Castellano D, Bajetta E, Panneerselvam A, Stephen S, Kocha W, O'Drisio T, et al. Everolimus plus octreotide long-acting repeatable in patients with colorectal neuroendocrine tumors: a subgroup analysis of the phase III RADIANT-2 study. Oncologist. 2013;18:46-53.

46. Kulke M, Shah M, Benson A, Bergsland E, Berlin J, Blaszkowky L, et al. Neuroendocrine tumors. Version I.J Natl Compr Canc Netw. 2015 Jan; 13(1):78-108.

47. Escudero MP, Acha J, Alonso V, et al. TNE intestinales. Guía Práctica de Diagnóstico, Tratamiento y Seguimiento de Tumores Neuroendocrinos, Versión 3. Barcelona: EdikaMed; 2016. p. 99-120.

48. Chagpar R, Chian Y, Xing Y, Cormier J, Feig B, Rashid A, et al. Neuroendocrine tumors of the colon and rectum: prognostic relevance and comparative performance of current staging systems. Ann Surg Oncol. 2013;20:1170-8

49. Kim M, Hur H, Min B, Baik S, Lee K, Kim N. Clinical outcomes for rectal carcinoid tumors according to a new (AJCC $7^{\text {th }}$ edition) TNM staging system: a single institutional analysis of 122 patients. J Surg Oncol. 2013;107:835-41.

50. Kunz P, Reidy-Lagunes D, Anthony L, Bertino E, Brendtro K, Chan J, et al. Consensus guidelines for the management and treatment of neuroendocrine tumors. Pancreas. 2013;42:557-77.

51. Öberg K, Knigge U, Kwekkeboom D, Perren A. Neuroendocrine gastro-entero-pancreatic tumors: ESMO clinical practice guidelines for diagnosis, treatment and follow up. Ann Oncol. 2012;23:124-30. 